\title{
Web 2.0 Students Adoption Model for Learning in Universities: A Case of Muni University, Uganda
}

\author{
Phelix Businge Mbabazi ${ }^{1}$, Nicholas Nkamwesiga ${ }^{2}$, Ritah Nafuna ${ }^{3}$, Patricia Kyomugisha ${ }^{4}$ \\ ${ }^{1,2,4}$ Kabale University, Ugandan \\ ${ }^{3}$ Muni University, Ugandan
}

\begin{abstract}
The Web 2.0 is generally known as web technologies, tools, and software applications that support collaborative effort to create and share data [1]. Web 2.0 renders new teaching and learning technologies and can transform the way lecturers and students interact with each other and how students interact with others beyond four walls of the classroom. This study determined the students' attitudes towards accepting the use of Web 2.0 Technologies for learning beyond the ordinary classroom. The Unified Theory of Acceptance and Use of Technology (UTAUT) model by Venkatesh et al. [2] was employed in this study to determine the strength of predictors for intention to accept and use Web 2.0 tools for teaching and learning. Questionnaires were administered to 100 students in the Faculty of Technoscience, Muni University. SPSS version 21 was used in data analysis. The results were presented in form of Tables, charts and means, percentages. P-values were used to predict the factors for the adoption of Web 2.0 in the process of teaching and learning in higher education. The results confirm several relationships in the UTAUT model as proposed by Venkatesh et al. [2] in predicting the behavioral Intention to use Web 2.0 for learning. The model shows that students' behavioral intention to use Web 2.0 depends on performance expectancy, effort expectancy, social influence and facilitating conditions. The study also showed that students use YouTube, Facebook and Google Apps but not LinkedIn, Social Bookmarking, Moodle, Zoom, Edx, MIT Courseware, and Dropbox among others.
\end{abstract}

Keywords: Web 2.0, Students, Adoption Model, Universities, Muni University, Uganda

\section{Introduction}

Administrators of educational institutions have been aiming at providing quality education to their learners [3]. Meeting the learning needs requires diligent work and continuous perseverance. In the current times, lecturers who use evolutionary tools and technologies in the process of teaching and learning could be able to spell a difference on the way teaching and learning get facilitated. Over the past three (3) decades, rapid evolution has happened in the area of information and communication technology (ICT). Specifically, in the last decade, the active trend in the prominence of social media tools has had a global impact on how people communicate [4]. According to Mutula in [5] social media platforms like Facebook, Twitter, LinkedIn, and Google+ among others have shown potential to become necessary disruptive technologies for building cutting-edge models of management education. The higher education teaching and learning have benefited a lot from these technologies due to the demands from many stakeholders to explore options available to enforce modern teaching and learning. Fleck in [6] argues that the application of ICT has fostered developments in e-learning as a support mechanism.

A good choice of educational-supporting tools to be integrated into classroom instruction helps to create engaging learners [7]. Web 2.0 technologies are offering educators new teaching and learning tools which can change the way lecturers and students interact with each other within and beyond four walls of the classroom.

The ICT adoption is key strategy in transforming University by integrating ICT in all the University functions [8], Muni University introduced the use of Moodle e-learning platform to facilitate teaching which supplemented by Amazon Kindle e-book readers and pre-loaded them with the relevant electronic learning materials, there is free access to Internet to all staff and students and every student is expected to own a mobile device to help access the E-learning platform. Given the about innovations, Muni University has not yet implemented the use of web 2.0 in learning process is in better position to implement the use of Web 2.0 in learning beyond the Four wall classroom. Therefore, this study explored the intention of students to use web 2.0 applications in the learning process by predicting the student's attitudes towards accepting to use web 2.0 tools in the teaching and learning process beyond four walls of the classroom using UTAUT model.

The study looked at the awareness and usage of the web 2.0 tools like Blogs, Wikis, Social Networking, Social Bookmarking, Podcast, Instant messaging, Google docs, and Video Chat, etc. It also looked student's intention to use Web 2.0 tools for Learning beyond the four walls of the classroom by adopting UTAUT model [2]. This study took place at 
Muni University located in West Nile, Arua District, Uganda from August 2018 to July 2019.

\section{Web 2.0}

The Web 2.0 is described as web technologies, tools, and software applications that support collective efforts to create and disseminate contents [1]. Alternatively, it is known as the "read/write Web" because it is the 2 nd generation of the web technology that enable users to read and also write content to the internet, thus providing them interactive features and services to manipulate (edit, share and delete) information they produce on the internet. Examples of these tools include instant messaging, Facebook, YouTube, Twitter, E-mail, Wikis, Blogs, LinkedIn, Google Maps, Podcast, Instant messaging, Social bookmarking, Moblogging, Vlogging or Video blogging, Flickr [8, $1]$.

It is vital to understand the importance of web 2.0 technologies such as instant messaging, google apps, social bookmarking, social networking sites, blogs, wikis, podcasts, discussion forums and others. According to Redecker et al. in [9] as cited in [1], the development of web 2.0 technologies has unlocked doors for effective and efficient learning practices. Effective use of these tools improves the quality learning, learner-centered and lifelong learning. While Okello [10] noted in his finding that web 2.0 tools are used for: collaboration with fellow scholars, the engagement of students' learning; social networking with students on academic matters, just for social networking among students; creating learning/training materials for students; sharing learning materials with learners; providing online and distance learning; online meeting among lecturers for the course; making classroom announcements to students; providing platform for sharing research findings; students assessment and submission of assignments; used as a platform for intelligence gathering of what students are thinking about lecturers; private business not related to teaching. Additionally, Teresita in [3] categorized the usage of web 2.0 as in enabling you to Participate, Share, Collaborate, Contribute, and Create content which summaries the findings of Okello [10].

Successful adoption which would involve planning, support, development and implementation of Web 2.0 technologies for learning requires support from all stakeholders of a learning environment, that is institutions, staff and students [11]. For implementation strategies to be successful, items like trainings, opportunities for discussions among facilitators, guidelines for assessment or content authoring, rating and anonymity have to be put into consideration [12]. Regardless of the studies so far carried out on the implementation strategies, research on user acceptance, educators and students' awareness of its usefulness are still calling for further research [13]. Thus, there is a knowledge gap regarding the factors that influence the increased use of web 2.0 tools, as a platform for facilitating learning in higher institutions of education.

As part of the study, a literature review was carried out and a number of widely referenced technology acceptance models that other researchers have been using over time to test technology acceptance were revealed as shown follows:

\section{Theory of Planned Behavior (TPB)}

Ajzen [14] proposed a model, shown in Figure 1, which measures what guides how human actions. It predicts the occurrence of a particular and intentional behavior. The theory of planned behavior is a theory which predicts deliberate behavior because behavior can be deliberative and planned. So, the three constructs can predict whether a person intends to do something that needs to be known:

- Whether the person is in favor of doing it ('attitude').

- How much the person feels social pressure to do it ('subjective norm').

- Whether the person feels in control of the action in question ('perceived behavioral control')

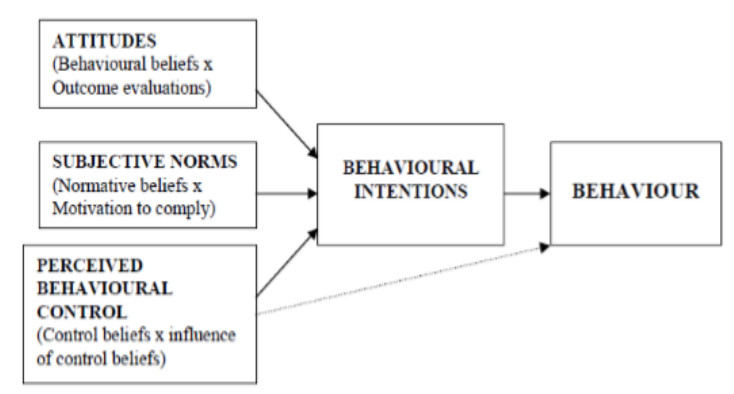

Figure 1. Theory of Planned Behavior [14]

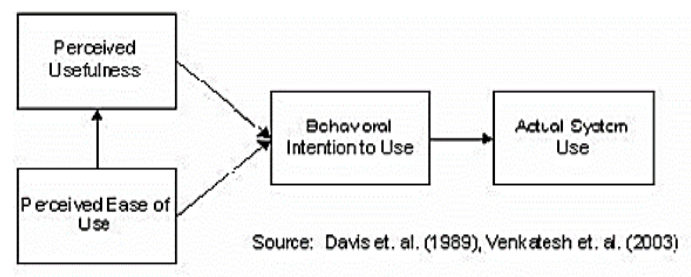

Figure 2. Technology acceptance model (TAM) [15]

Technology acceptance model (TAM) by Davis [15], shown in Figure 2, posited that perceived usefulness and perceived ease of use determine an individual's intention to use a system with intention 
to use serving as a mediator of actual system use. Perceived usefulness is also seen as being directly impacted by perceived ease of use. Attempts to extend TAM have generally taken one of three approaches: by introducing factors from related models, by introducing additional or alternative belief factors, and by examining antecedents and moderators of perceived usefulness and perceived ease of use.

\subsection{UTAUT}

The Unified Theory of Acceptance and Use of Technology (UTAUT) has been used by several educational institutions and research to investigate the user's attitudes towards accepting ICT solution regardless of the level of available infrastructures and support administrations. There is however a concern as to whether students are prepared to accept the available web 2.0 technology into their learning.

UTAUT's formulation was to integrate the fragmented theory and research on individual acceptance of information technology into a unified theoretical model [2]. According to Venkatesh et al. [2], eight specific models of the determinants of intention and usage of information technology were compared and conceptual and empirical similarities across them were integrated to formulate UTAUT.

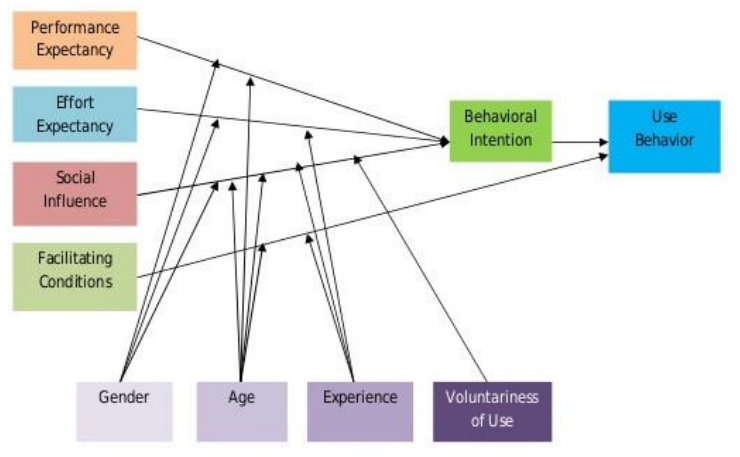

Figure 3. UTAUT Model by Venkatesh et al. [2]

The UTAUT, which is shown in Figure 3, consists of four (4) independent variables of Performance Expectancy (PE), Effort Expectancy (EE), Social Influence (SI), and Facilitating Conditions (FC) which influence dependent variables of behavioral and usage. Gender, age, experience, and volunteers of system use have indirectly influenced the dependent variables via the four (4) independent variables. Behavioral intention is a critical predictor of technology use [2]:

i. Performance expectancy: "The degree to which an individual believes that using the system will help him or her to attain gains in job performance" [2]. PE is hypothesized to moderate the influence on behavioral intention by gender and age.

ii. Effort expectancy: "The degree of ease associated with the use of the system" [2]. Effort expectancy hypothesized to moderate the influence on behavioral intention by gender and age, and experience.

iii. Social influence: "The degree to which an individual perceives that important others believe he or she should use the new system" [2]. Social influence, hypothesized to moderate the influence on behavioral intention by gender and age, and experience, and volunteers of system.

iv. Facilitating conditions: "The degree to which an individual believes that an organizational and technical infrastructure exists to support use of the system" [2]. Hypothesized to moderate the influence on behavioral intention by age, and experience.

\section{Research Model}

In this study, the researchers used UTAUT to study acceptance and use of Web 2.0 by the Muni University students.

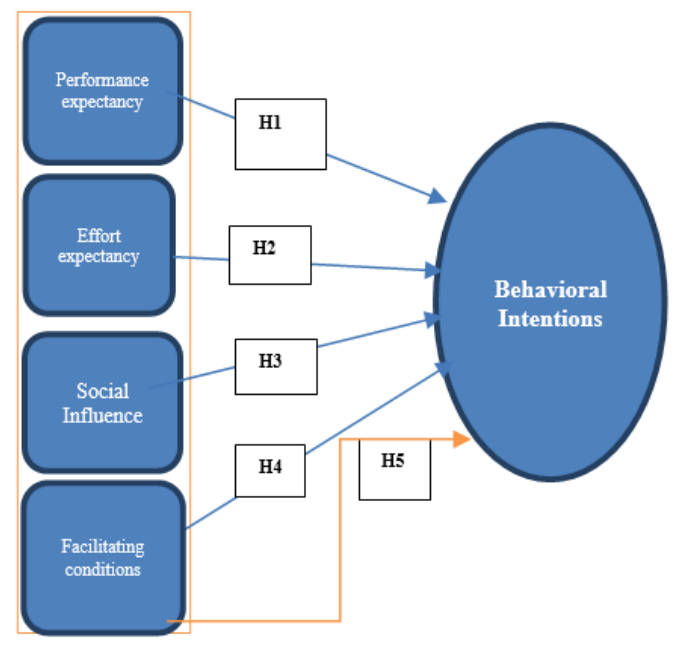

Figure 4. Research Model - Web 2.0 Students Adoption Model for Learning

The four (4) factors influence the use of Web 2.0 technologies in learning according to the UTAUT are: performance expectancy, effort expectancy, social influence, and facilitating conditions. This study did not consider the moderating effect of gender, age, experience, and voluntariness. Because our participants were all University students, the gender, age, experience, and voluntariness are relatively similar. Therefore, we have made some 
alterations to our research model as highlighted in Figure 4. The following Hypothetical $(\mathrm{H})$ Questions were tested in the research model:

- H1: Effort expectancy positively influences behavioral intentions to use Web 2.0 Technologies for learning by students Universities.

- H2: Performance expectancy positively influences University student's behavioral intention to use Web 2.0 Technologies.

- H3: Social Influence conditions positively influence behavioral intentions of students at the University to use Web 2.0 Technologies for Learning and research.

- H4: Facilitating conditions directly influence behavioral intentions of student's use behavior of Web 2.0 Technologies for learning.

- H5: Both performance expectancy, effort expectancy, social influence, and facilitating conditions directly influence behavioral intentions of student's use behavior of Web 2.0 Technologies for learning.

\subsection{Methodology}

This study used a cross-sectional survey research design in assessing the student's awareness and use of web 2.0 technologies in learning. This study targeted a population of 100 students from the faculty of TechnoScience, Muni University. The study used a self-made questionnaire which predicted the intention to use web 2.0 by adapting an adoption theory (Theory of Planned behavior and UTAUT).

The results were analyzed using Statistical Package for the Social Sciences (SPSS) version 21 and results presented in form of Tables and $\mathrm{P}$ values were used to predict the adoption factors of Web 2.0 technologies in the learning process of the students.

\section{Findings}

The analysis of the data indicate that the measures are robust in terms of their internal consistency reliability as indexed by composite reliability. The reliability of the collected data in this study was assessed by the Statistical Package for Social Science (SPSS). Cronbach's alpha of 0.725 was obtained which exceed the recommended threshold value of 0.60 .

The data for this study was collected using online survey of the Muni University students from the month of August, 2018 to July, 2019. The questionnaire included a section on demographic information and UTAUT measurements. The instrument was tested with a group of 20 students before the final launching of the survey. These students were selected based on availability and willingness to participate. In total, 92 responses were obtained and this represents a response rate of approximately $92 \%$ of which 58 were from males and 34 were females. The distribution of the ages of the respondents is as follows: 16-25; were 81 students, 26-23 were 6 students and 36-45 were 5 students. The age of the respondents is shown in Figure 5.

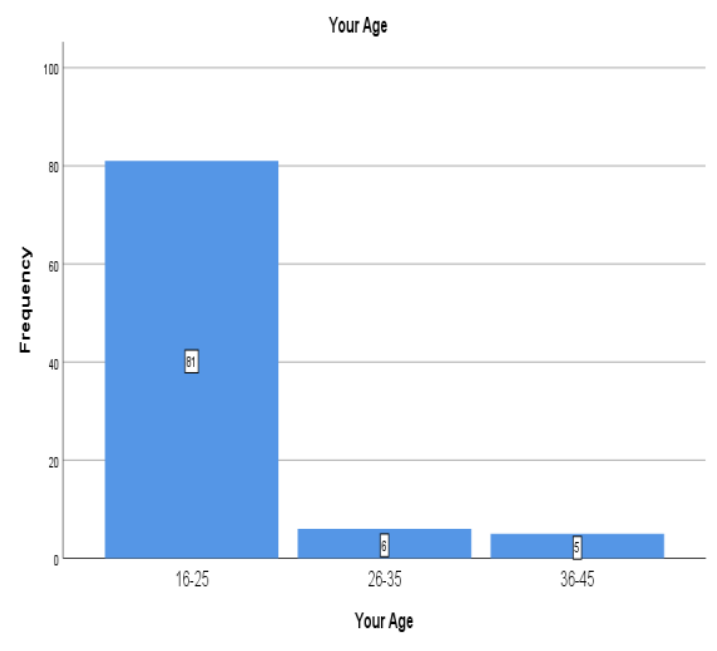

Figure 5. Age brackets of Respondents

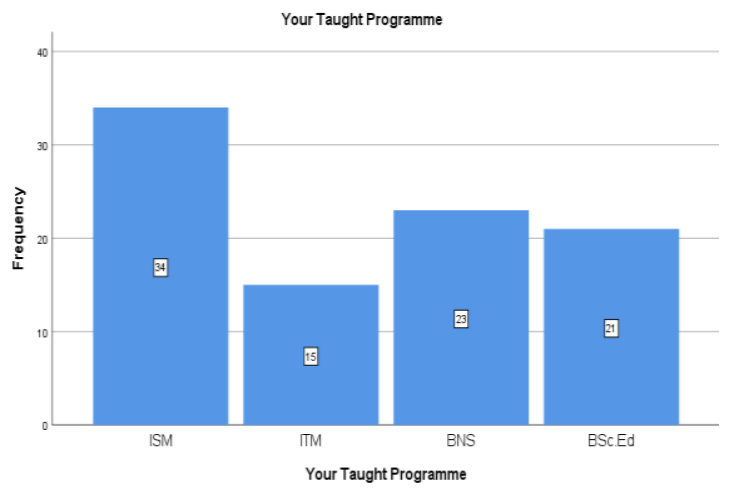

Figure 6. Programme of study of Respondents

As shown in Figure 6, the study showed that majority of the participants were from Bachelor of Information Systems (ISM) with $34 \%$ followed by Bachelor of Nursing Science (BNS) with 23\% then $21 \%$ of Bachelor of Science Education (BSc. Ed) and Bachelor of Information Technology (ITM) $15 \%$.

The findings in the Table 1 showed that students know and always use YouTube (55\%), Facebook $(51 \%)$ and Google Apps Usage (37\%). While others they know but do not use Twitter (17\%), Wiki (17\%) 
and Blogs $(8 \%)$. The findings further revealed that students they don't know LinkedIn Usage, Social Bookmarking Usage, Video Blogging Usage, Flickr Usage, Moodle Usage, Zoom Usage, Wiki Spaces Usage, Edx Usage, MIT Courseware Usage, TED Ed Usage, Endnote Usage, Dropbox Usage.

Table 1. Web 2.0 Awareness

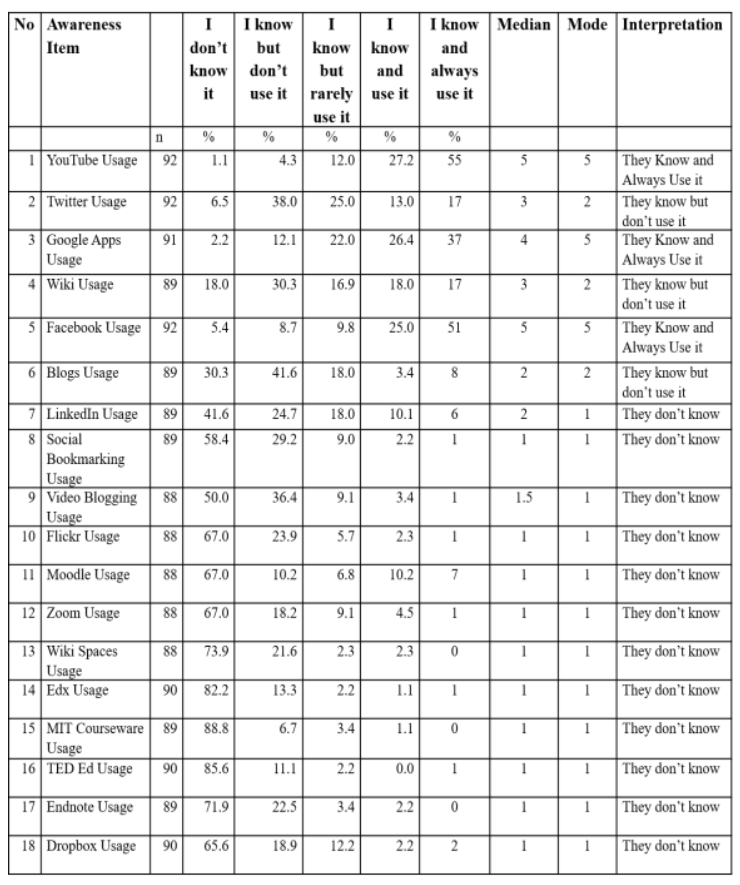

\subsection{UTAUT Factors Measurements}

The UTAUT factors were measured by the items shown in Table 2. Each item was scored on a 4-point fully labelled rating scale with the agree/disagree format. These items are common in many Mobile Learning studies and it is often necessary for researchers to adapt the item wording to suit the context [16]. For the current study, the items were modified to enhance comprehension by the respondents, based on feedback from the pilot exercise which involved 20 respondents.

\subsection{Regression Analysis}

The researchers used regression analysis to investigate the influence of performance expectancy, effort expectancy, social influence and facilitating conditions on Behavioral Intention. The results show that performance expectancy, effort expectancy, social influence and facilitating conditions significantly affect behavioral intention to use Web 2.0 by students in the process of learning as shown Figure 7 and Table 3.
Table 2. The UTAUT Items

\begin{tabular}{|c|c|c|c|c|c|}
\hline Constructs & Items & \begin{tabular}{|l|} 
Strongly \\
Disagree
\end{tabular} & \begin{tabular}{|l|} 
Disagree \\
\end{tabular} & Agree & \begin{tabular}{|l} 
Strongly \\
Agree
\end{tabular} \\
\hline \multirow[t]{4}{*}{$\begin{array}{l}\text { Performance } \\
\text { expectancy }\end{array}$} & $\begin{array}{l}\text { I find Web } 2.0 \text { technologies in } \\
\text { my institution useful to my } \\
\text { study }\end{array}$ & 29.9 & 16.6 & 1.6 & 4.5 \\
\hline & $\begin{array}{l}\text { Using Web } 2.0 \text { technologies } \\
\text { helps me to accomplish tasks } \\
\text { more quickly } \\
\end{array}$ & 21.7 & 22.9 & 4.5 & 1.919 \\
\hline & $\begin{array}{l}\text { Using Web } 2.0 \text { Technologies in } \\
\text { my institution increases my } \\
\text { productivity }\end{array}$ & 19.1 & 23.6 & 7.0 & 2.5 \\
\hline & $\begin{array}{l}\text { Using Web } 2.0 \text { Technologies in } \\
\text { my institution increases my } \\
\text { students' chances of getting } \\
\text { good grade }\end{array}$ & 19.1 & 24.2 & \begin{tabular}{|l|}
7.6 \\
\end{tabular} & 2.5 \\
\hline \multirow[t]{4}{*}{$\begin{array}{l}\text { Effort } \\
\text { Expectancy }\end{array}$} & $\begin{array}{l}\text { My interaction with Web2.0 } \\
\text { technologies in my institution } \\
\text { is clear and understandable } \\
\end{array}$ & 15.3 & 26.1 & 11.5 & 6 \\
\hline & \begin{tabular}{|l|} 
It is easy for me to become \\
skillful at using the Web 2.0 \\
Technologies in my institution
\end{tabular} & \begin{tabular}{|l|}
15.3 \\
\end{tabular} & 31.2 & \begin{tabular}{|l|}
6.4 \\
\end{tabular} & 6 \\
\hline & $\begin{array}{l}\text { I find it easy to use Web } 2.0 \\
\text { Technologies in my institution }\end{array}$ & 9.6 & 35.7 & 6.4 & 2.5 \\
\hline & $\begin{array}{l}\text { Learning to operate Web } 2.0 \\
\text { Technologies provided by my } \\
\text { institution is easy }\end{array}$ & 14.6 & 28.7 & 8.9 & 1.3 \\
\hline \multirow[t]{4}{*}{$\begin{array}{l}\text { Social } \\
\text { Factors }\end{array}$} & $\begin{array}{l}\text { People who influence my } \\
\text { behavior think that I should use } \\
\text { Web } 2.0 \text { technologies for my } \\
\text { classes }\end{array}$ & 11.5 & 19.7 & 15.9 & 6.4 \\
\hline & $\begin{array}{l}\text { People who are Important to } \\
\text { me think I should use Web } 2.0 \\
\text { technologies for my classes }\end{array}$ & 8.3 & 24.8 & 17.2 & 1.9 \\
\hline & $\begin{array}{l}\text { The senior management of the } \\
\text { University has been helpful in } \\
\text { my use of Web } 2.0 \\
\text { technologies for my classes }\end{array}$ & 7.6 & 26.8 & \begin{tabular}{|l|}
14.0 \\
\end{tabular} & 5.7 \\
\hline & $\begin{array}{l}\text { In general, My University has } \\
\text { supported the use of Web } 2.0 \\
\text { technologies for my class }\end{array}$ & 19.1 & 24.8 & 6.4 & 3.2 \\
\hline \multirow[t]{3}{*}{$\begin{array}{l}\text { Facilitating } \\
\text { conditions }\end{array}$} & $\begin{array}{l}\text { I have the resources necessary } \\
\text { to use Web } 2.0 \text { technologies for } \\
\text { my classes }\end{array}$ & 19.1 & 22.9 & 7.0 & 3.8 \\
\hline & \begin{tabular}{|l|} 
I have the Knowledge \\
necessary for use of Web 2.0 \\
technologies \\
\end{tabular} & \begin{tabular}{|l|l|}
14.6 \\
\end{tabular} & \begin{tabular}{|l|}
29.9 \\
\end{tabular} & \begin{tabular}{|l|}
7.6 \\
\end{tabular} & 6 \\
\hline & $\begin{array}{l}\text { A specific person (or Group) is } \\
\text { available for assistance with } \\
\text { difficulties I experience with } \\
\text { web } 2.0 \text { technologies } \\
\end{array}$ & 8.9 & 27.4 & 10.8 & 5.7 \\
\hline \multirow[t]{3}{*}{$\begin{array}{l}\text { Behavioral } \\
\text { Intention }\end{array}$} & \begin{tabular}{|l|} 
I intend to use Web 2.0 \\
technologies Next Semester
\end{tabular} & 21.7 & 222.9 & 4.5 & 3.2 \\
\hline & $\begin{array}{l}\text { I predict I would use Web } 2.0 \\
\text { technologies Next Semester }\end{array}$ & \begin{tabular}{|l|l|}
17.2 \\
\end{tabular} & 24.2 & \begin{tabular}{|l|}
7.0 \\
\end{tabular} & 3.8 \\
\hline & \begin{tabular}{|l|} 
I intend to ask my students to \\
use Web 2.0 technologies Next \\
Semester
\end{tabular} & 14.0 & 26.1 & 10.8 & 2.5 \\
\hline
\end{tabular}

Scale labels: 1-Strongly disagree, 2-Disagree, 3-Agree, 4Strongly Agree

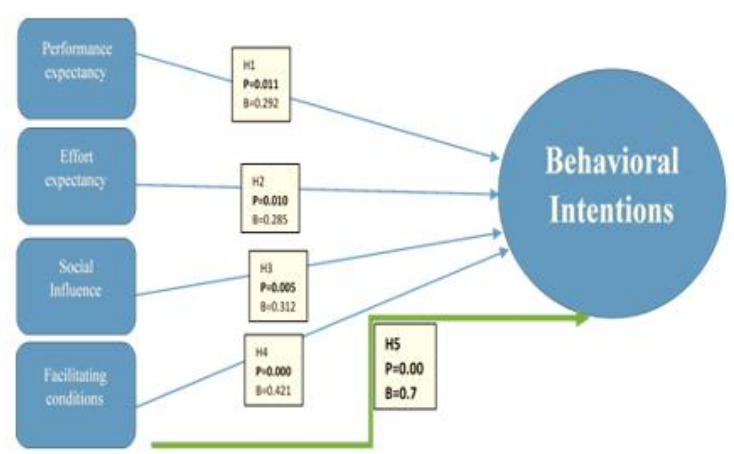

Figure 7. Simple Linear Regression 
Table 3. Simple Linear Regression

\begin{tabular}{|l|l|l|l|l|l|}
\hline Construct & B & F & R Squared & Sig & Interpretation \\
\hline $\begin{array}{l}\text { H1. Does Performance } \\
\text { expectancy positively influence } \\
\text { University students' behavioral } \\
\text { intention to use Web 2.0 } \\
\text { Technologies? }\end{array}$ & 0.292 & 6.817 & 0.730 & 0.011 & Significant \\
\hline $\begin{array}{l}\text { H2. Does Effort expectancy } \\
\text { positively influence behavioral } \\
\text { intentions to use Web 2.0 } \\
\text { Technologies for learning by } \\
\text { students of Universities? }\end{array}$ & 0.285 & 6.892 & 0.069 & 0.010 & Significant \\
\hline $\begin{array}{l}\text { H3. Does Social Influence } \\
\text { conditions positively influence } \\
\text { behavioral intentions of students } \\
\text { of the University to use Web 2.0 } \\
\text { Technologies for Learning and } \\
\text { research }\end{array}$ & 0.312 & 8.206 & 0.086 & 0.005 & Significant \\
\hline $\begin{array}{l}\text { H4. Do Facilitating conditions } \\
\text { directly influence University } \\
\text { student's use behavior of Web 2.0 } \\
\text { Technologies for learning? }\end{array}$ & 0.421 & 16.791 & 0.167 & 0.000 & Significant \\
\hline $\begin{array}{l}\text { H5. All PE, EE, SI, FC directly } \\
\text { influence the University student's } \\
\text { use behavior of web 2.0 } \\
\text { technology }\end{array}$ & 0.791 & 21.579 & 0.227 & 0.000 & Significant \\
\hline
\end{tabular}

Table 3 above shows that there is a significant relationship $(\mathrm{p}=0.011$ which is less than 0.05$)$ between performance expectancy (PE) and University student's behavioral intention in influencing use of Web 2.0 Technologies which means that the variation $(\mathrm{R}$ squared $=0.730)$ explained by the model is not due to chance. One unit change in Performance Expectancy brings in 0.292 change $(B=0.292)$ in behavioral intention in use of Web 2.0 Technologies. The findings further showed that Effort expectancy EE) sig=0.010, Social Influence (SI) sig=0.005 and Facilitating conditions (FC) sig $=0.000$ directly influences in behavioral intention in use of Web 2.0 Technologies for example the Beta (B) coefficient shows that for every One unit of change in Effort expectancy, Social Influence and Facilitating conditions directly influences $0.285, \quad 0.312$ and 0.421 change respectively in behavioral intention in use of Web 2.0 Technologies. Table 3 also shows that all performance expectancy, Effort expectancy, Social Influence and Facilitating conditions combined directly influence the University student's use behavior of web 2.0 technology. This is indicated by the sig-value of 0.000 and the Beta (B) coefficient where by one unit change in all the four factors PE, EE, SI, FC contributes 0.791 changes in behavioral intention in use of Web 2.0 Technologies.

\section{Discussion}

The study investigated the use of web 2.0 technologies as a new way of facilitating teaching and learning this study determined the students' attitudes towards accepting the use of web 2.0 for learning beyond the four-walled classroom. The study revealed that the highly known and used web 2.0 technologies by students of Muni University are YouTube, Facebook and Google apps with 55\%,
$51 \%$ and $37 \%$ respectively. The other web 2.0 technologies were found to fall below $30 \%$ usage rate. With the current anecdotal need for internetaided teaching and learning among many stakeholders in institutions of higher learning, the investigated usage rate seems to lag behind the average expectations. Many institutions are advocating for blended form of teaching and learning (i.e., online/eLearning and physical modes of teaching and learning) with the aim of reducing physical interaction among learners and their learning facilitators. This study, therefore, serves to awaken the concerned learning managers in higher institutions of learning to create awareness of web 2.0 among their learners. The study has also resulted into key milestone in the under-researched area awareness and usage of web 2.0 in Uganda.

The Unified Theory of Acceptance and Use of Technology (UTAUT) model by Venkatesh et al., [2] was employed in this study to determine the strength of predictors for intention to accept and use Web 2.0 tools for teaching and learning. The constructs investigated under this study are Performance, expectancy, Effort expectancy, Social influence, and Facilitating conditions. The research found out that the highlighted constructs positively influence University students' behavioral intention to use web 2.0 technologies. One unit change in all the four factors PE, EE, SI, and FC contributes 0.791 changes in behavioral intention in use of Web 2.0 Technologies. The results of this study are supported by the model of Venkatesh et al., [2] during their study about User Acceptance of Information Technology.

\section{Conclusion}

The results confirm several of the relationships in the UTAUT model which was proposed by Venkatesh et al. [2] in predicting the behavioral Intention to use Web 2.0 technologies for learning. The UTAUT model shows that students' behavioral intention to use Web 2.0 depends on performance expectancy, effort expectancy, social influence and facilitating conditions. The study also showed that students use YouTube, Facebook and Google Apps more than the way they use LinkedIn, Social Bookmarking, Video Blogging, Flickr, Moodle, Zoom, Wiki Spaces, Edx, MIT Courseware, TED Ed, Endnote, and Dropbox which would be vital for learning especially during and after world-wide lockdowns brought about by pandemics like Covid19, which call physical distancing among learners and other people.

\section{Limitations and Suggestions}

The study only examined the acceptance of Web 2.0 usage in one University among students, the 
results may not be generalized to other Universities and countries. Therefore, the researchers suggest that a future researcher validate the model and findings in other Universities or other countries and also research on lecturer's acceptance. With the challenges that have been presented by Covid-19 pandemic, there is a possibility of change in the mindset and preparations to start using web 2.0 technologies in teaching and learning both in higher and lower institutions of learning. There is therefore a need to carry out further research aimed at assessing the acceptance of web 2.0 technologies in teaching and learning after the Covid 19 pandemic has settled. Future researchers can also research on the use of web 3.0 in teaching and learning.

\section{References}

[1] Usoro, A. and Echeng, R., (2015). "Model of acceptance of Web 2.0 technologies for increased participation in learning activities", International Journal of Intelligent Computing and Cybernetics, Vol. 8 Issue 3 pp. $208-221$.

[2] Venkatesh, V., Morris, M., Davis, G.B., and Davis, F.D., (2003). "User Acceptance of Information Technology: Toward a Unified View," MIS Quarterly, Vol. 27, No. 3, pp. 425-478.

[3] Mijares, T. S., (2014). "The status and adoption factors of web 2.0 technologies in the teaching and learning process in higher education". ASAIHL International Conference 2014 Nanyang Technological University, Singapore December pp. 4-5.

[4] Thomas, M. and Thomas, H., (2012). "Using new social media and Web 2.0 technologies in business school teaching and learning". Journal of Management Development. 31(4), 358 - 367.

[5] Mutula, S M., (2013). Ethical Dimension of the Information Society: implications for Africa. In Information Ethics in Africa: Cross-Cutting Themes, Pretoria: AC, pp. 29-42.

[6] Fleck, J. (2008), "Technology and the business school world", Journal of Management Development, Vol. 27 No. 4, pp. 415-424. https://doi.org/10.1108/0262171081086 6750 (Access Date: 17 August, 2019).

[7] Byrne, R. (2009). The Effect of Web 2.0 on Teaching and Learning. Teacher Librarian, Vol. 37, Issue 2. https://www.learntechlib.org/p/70571/ (Access Date: 12 July, 2019).

[8] Tusubira, F. (2005). "Supporting universities' ICT developments: The Makerere University experience". Africa Development, Vol. 30, Issue 1, pp. 86-97. https://doi.org/10.4314/ad.v30i1.22214.

[9] Redecker, C., Ala-Mutka, K., Bacigalupo, M., Ferrari, A. and Punie, Y., (2009). "Learning 2.0: the impact of Web 2.0 innovations on education and training in Europe, final report", JRC Scientific and Technical Report, EUR 24103 EN: http://ipts.jrc.ec.europa.eu/publications/pub.cf m?id1/42899 (Access Date: 24 September, 2019).

[10] Okello-Obura, C., (2015). Web 2.0 technologies application in teaching and learning by Makerere university academic staff. Library Philosophy and Practice (e-journal). http://digitalcommons.unl.edu/libphilprac/ 1248 .

[11] Jucevičienė, P. and Valinevičienè, G., (2010). "A conceptual model of social networking in higher education", Electronics and Electrical Engineering, Vol. 6 No. 102, pp. 55-58.

[12] Kennelly, P., (2009). "An online social networking approach to reinforce learning of rocks and minerals", Journal of Geoscience Education, Vol. 57 No. 1, pp. 33-40.

[13] Echeng, R. and Usoro, A., (2014). "Factors of acceptance and use of Web 2.0 technologies for effective implementation in higher education", Present Level of Use in Two Countries. ICICTE 2014 Proceedings, Kos Island Greece, 3-5, pp. 82-94.

[14] Ajzen, I. (1991). "The Theory of Planned Behavior: Organizational Behavior and Human Decision Processes. Vol. 50, Issue 2, pp. 179-211.https://www.sciencedirect. com/science/article/pii/074959789190020T (Access Date: 10 December, 2019).

[15] Davis, F.D., (1989). "Perceived Usefulness, Perceived Ease of Use, and User Acceptance of Information Technology," MIS Quarterly, Vol. 13, No. 3, pp. 319-340.

[16] Andergassen, M., Behringer, R., Finlay, J., Gorra, A. and Moore, D., (2009). "Weblogs in higher education: why do students (not) blog?", Electronic Journal of e-Learning, Vol. 7 No. 3 . 